\title{
ON THE MECHANICAL APPLIANCES \\ USED IN THE CONSTRUCTION OF THE HEADING UNDER THE SEVERN, FOR THE SEVERN TUNNEL RAILWAY.
}

By Mr. John J. GEACH, of New Passage, near Bristol.

The object of this paper is to record the results attained in actual every-day work by the machinery used at the Severn Tunnel, without entering into any comparison of different classes of rock drills. Simplicity in all cases has been aimed at, so that ordinary labourers could work the machines with very little practice.

The subject has been arranged under the following heads:-

Soundings by machine.

Sinking of the first Shaft.

Driving the Heading by hand, by the McKean machinc, and by the writer's machine.

Details of the Rock-Drilling Machine in use.

Details of Rock-Drill Carriage.

Details of Air-Compressor, and method of cooling.

Details of Pumping Machinery.

Soundings.-These were taken by the aid of the machine shown on the table. It consists of a light drum, round which the brass sounding wire was coiled; a worm on the same shaft gearing into a wormwheel, and an adjustable index-hand and plate. The lead used was $12 \mathrm{lb}$. weight. This machine enabled two soundings per minute to be taken in $60 \mathrm{ft}$. of water. The plan followed was to sound on parallel lines north and south of the parliamentary centre line, at intervals of $30 \mathrm{ft}$. apart. After about twenty of these lines had been sounded and plotted, a final line was decided on as the centre line of the tunnel; and along this soundings were again taken moro numerous 
than before, and so well did these soundings agree that two would often plot on the same spot, although taken at different times. The machine shown was designed and made for the purpose, and was used in a row boat about $20 \mathrm{ft}$. Iong and $6 \frac{1}{2} \mathrm{ft}$. beam. Owing to the current, the soundings were only taken about half an hour before and after high and low water. A general section of the river Severn along the line of the tunnel is shown in Fig. 1, Plate 31 ; and the enlarged section in Fig. 2 shows the shaft, and the distance to which the heading has now been driven.

Sinking of the first Shaft.-As soon as the final centre line for the tunnel was fixed, the position of the shaft was marked out, and sinking was commenced by hand through sand, sandstone, and marl, down to $45 \mathrm{ft}$. deep, at which depth the hand-pump, skips, \&c., failed to keep the water under. As a temporary measure one of Tangye's "special" pumps was put to work in the shaft, and by its aid the sinking was carried $25 \mathrm{ft}$. further, when it got overpowered. A bucket-lift on the Cornish plan was then erected, which kept the water under at 4 strokes per min. As the shaft went down, a plungerlift was coupled on the same engine, working in a tank, into which the same bucket-lift raised the water. With the aid of these lifts. the shaft was sunk to the required depth of $200 \mathrm{ft}$, having passed through top soil, sand, sandstone, marl, conglomerate, pennant, clay shales, coal shales, millstone grit, limestone boulders and clay, and into ironstone. When down to the proper depth, another similar plunger-pump was erected at the bottom of the shaft, and the one with which the shaft had been sunk was also fixed at the bottom: so that there were two plunger-lifts fixed for draining the heading. Two suitable cages were now erected in the shaft, with wood guides, and were provided with catching gear. These cages were suspended by $\frac{7}{8}$ in. round steel wire-ropes, both ropes working on the same drum, but wound on in opposite directions. The drum was $6 \mathrm{ft}$. diam., and was geared 1 to 4 to a pair of horizontal engines with $10 \mathrm{in.}$ by 14 in. cylinders, fitted with reversing gear and with two brakes, one on the drum direct and the other on the crank-shaft of the engine. 
Driving the Heading.-As soon as the above work was finished, the driving of the heading was started by hand labour, and the progress that could be made was not more than $1 \mathrm{ft}$. per. 24 hours. The McKean rock drills were then put at work, and for the next month the progress averaged $2 \mathrm{ft}$. per 24 hours. These machines worked from January 1875 until the November following, when they were entirely worn out; the average rate attained was $6 \mathrm{ft}$. per 24 hours. In November 1875 the author's improved rock-drilling machines were put at work, and in driving by their aid till the end of January 1876 the average speed in the same pennant rock had risen to $8 \mathrm{ft}$. per 24 hours. This has since been much exceeded: 20 yards in 6 days, or at the rate of $10 \mathrm{ft}$. per day, has been driven in solid rock; and when the ground was more favourable as much as 26 yards in the same time, or at the rate of $13 \mathrm{ft}$. per day. Not only has this been done, but the arerage speed in the same rock is now rather more than $9 \mathrm{ft}$. per 24 hours.

Rock-Drilling Machine.-This rock drill differs from most rockdrilling machines in being made strong and heavy, and having a very efficient system of rotation and method of holding the drill. 'The latter feature is quite new, as far as the writer is aware; its extreme simplicity, and the entire absence of any loose parts, must commend it to practical men, whilst its holding power is ample. It is also self-centering, which is very necessary with such men as work these drills, being merely ordinary labourers. This method of holding the drill has never been found to give any trouble, and the tool is also easily extracted.

The following is an example of the time occupied in boring by this machine for blasting, the work being done $4432 \mathrm{ft}$., or more than $\frac{3}{4}$ mile, from the bottom of the shaft, which is $200 \mathrm{ft}$. deep; a sample of the rock is exhibited on the table, showing some parts of the holes bored. The rock-drill carriage was moved forward from a siding at 11.30 a.m., and taken to the face, coupled up, and fixed; at $11.41 \mathrm{a.m}$. the machines commenced boring, and in 1 hour $6 \mathrm{~min}$. twenty holes were finished, averaging $2 \mathrm{ft}$. deep each; the rock-drill carriage was then uncoupled and run back to the siding, and the 
holes were charged with dynamite ready for firing at 1 p.m.; total time occupied in boring and charging, 1 hour $19 \mathrm{~min}$. 'This is an ordinary speed, no means having been taken to obtain extra quick work. Two of the rock-drilling machines were used, one on each side of the carriage; and the left-hand machine was worked by a man whose experience of machine drilling only extended over twelve days. The following, are the particulars of a few of the holes in the order in which they were bored on this occasion by this machine and $\operatorname{man}:-$

\begin{tabular}{|c|c|c|c|c|c|c|}
\hline \multirow{2}{*}{$\begin{array}{l}\text { No. of } \\
\text { hole. }\end{array}$} & \multirow{2}{*}{$\begin{array}{c}\text { Boring } \\
\text { commenced. }\end{array}$} & \multirow{2}{*}{$\begin{array}{l}\text { Time } \\
\text { occupied in } \\
\text { chnnging } \\
\text { drill. }\end{array}$} & \multirow{2}{*}{$\begin{array}{l}\text { Boring } \\
\text { fivished. }\end{array}$} & \multirow{2}{*}{ Total Time. } & \multicolumn{2}{|c|}{ Depth Bured. } \\
\hline & & & & & Total. & Per min. \\
\hline No. & II. M. & Sec. & II. Y. & Min. & Inch. & Inch. \\
\hline 1 & 1141 & 20 & 1144 & 3 & 18 & 60 \\
\hline 2 & 1146 & 20 & 1151 & 5 & 26 & $5 \cdot 2$ \\
\hline 3 & 1152 & 50 & 1159 & 7 & 28 & 40 \\
\hline 4 & 121 & 15 & 125 & 4 & 24 & $6 \cdot 0$ \\
\hline 5 & 126 & 55 & $1210 \frac{1}{2}$ & $4 \frac{1}{2}$ & 31 & 6.9 \\
\hline 6 & 1215 & 35 & $1219 \frac{1}{2}$ & $4 \frac{1}{2}$ & 24 & $5-3$ \\
\hline
\end{tabular}

* Ineluding the thme oceupied in changing the drill.

These six and the remaining four of the ten holes were all bored by two drills; it is found as a rule that four drills put down $40 \mathrm{ft}$. depth of hole, or each drill bores $10 \mathrm{ft}$. before wanting sharpening, which is done in the forge, no fitting or grinding being required. These holes are all bored truly cylindrical, proving the perfect rotating and boring power of these rock drills. Other machines that have been used by the writer have been found defective in this particular, leading to the drill being often jammed in the hole.

The Rock-Drilling Machine is shown in Figs. 3 to 8, Plates 32, 33 ; it consists of a cylinder, with piston and rod and valve-gear, mounted on a slide-bed. The cylinder $A$ has no loose covers or split glands, which in some machines have proved a source of great trouble 
and expense. The piston and piston-rod $B$ are made in one piece of steel. The piston has two rings of steel, and the rear end of the rod, $1 \frac{1}{2}$ in. diam., is cut with spiral grooves making one complete turn in 32 in.; this fits into a long cylindrical nut $\mathbf{C}$, on the centre of which is formed solid a ratchet-wheel $3 \frac{1}{4}$ in. diam., having 28 teeth. Into these teeth a paul engages, Fig. 5, to prevent the rotation of the drill and piston-rod in more than one direction. When the pistonrod is making its full stroke, the panl slips over three teeth per stroke and holds them; the rotation of the drill and piston-rod is effected in the backward stroke, and the forward blow takes a straight direction.

The front end of the piston-rod is $2 \frac{1}{4}$ in. diam., and holds the drill $\mathrm{D}$, Fig. 3 , in a conical socket, which is $1 \frac{1}{2}$ in. diam. in front, and coned to $1 \frac{1}{8}$ in. at 4 in. back. A lreyway $1 \frac{1}{4}$ in. by $\frac{1}{4}$ in. is cut through the rod, for the purpose of forcing out the drill when another is required. Over the end of the piston-rod in which the coned hole is bored, a steel hoop $\frac{3}{4} \mathrm{in}$. thick is shrunk, to prevent the coned end of the drill from bursting the end of the piston-rod, and to give a certain amount of elastic clip. It is found that with this cone a drill never slips or sticks so fast that it cannot be readily driven out. No special precautions are necessary, except that as the coned end of the drill is entered into the end of the piston-rod it is passed through the hand and so cleaned. No driving in of the drill is required; the drill is entered, held loosely by the hand in place, and the first stroke of the machine fastens it; no further precautions are necessary. The drill is securely and truly held, and has never been known to fail in any degree during months of continual work. The end of the drill is turned to the same cone as the socket in the piston-rod, but no grinding in or special fit is required.

The valve genr consists of two pistons on one rod E, Fig. 3, sliding in a cylinder; the air is taken in between these pistons, and by their motion is alternately admitted to and let out of the ends of the drill cylinder A. The ports are small, 1 in. long, $\frac{3}{8}$ in. wide, and $\frac{1}{2}$ in. deep, and are placed $\frac{1}{2}$ in. short of the cylinder ends to form a cushion. This protection is more than enough, and the piston never strikes the ends of the cylinder, even if run full speed without any drill in the 
rod. The valve-pistons have for packing $C$ rings with a spiral spring behind, one in each piston; the solid part of the piston is toward the port, Fig. 6, so that there is no risk of the ring getting into the port. The valve is driven by a ball tappet $F$ on the piston-rod, through a quadrant mounted on a pin, as shown in the plan, Fig. 3.

The method of feeding the drill forward as it bores the hole is by a $1 \frac{1}{2}$ in. feed-sorew $G$ rotated by hand. The writer has tried automatic feed, and is convinced that, in such a variable material as is the rock met with in heading-driving and shaft-sinking, hand foed is the simplest. On paper, automatic gear looks best; but when machines come to work, as they have to do, under varying conditions and hard usage, simplicity is of the greatest importance. It is found also in the work that if the man working the machine is encouraged he will soon learn to feed the drill forward exactly as the hole is bored. Comparisons of hand with automatic gear are often based on the work of a self-acting lathe or other shaping machine; but this is not, in the writer's opinion, a fair comparison. In the one case the tool is acting on a material which is known and has been seen; and in the other the working is in the dark to a great extent, owing to the presence in the rock of joints and backs and layers of soft material. The writer tried the antomatic gear of the McKean drill in ironstone with thin joints of clay shale, and found it would not bore through this rock and shale at an oblique angle with the joints; and yet the same machines, by using the hand-feed gear, bored through both the ironstone and the clay-shale joints.

The machine bed $H$ is held to the clamp on the crossbar $J$ of the rock-drill carriage by clip-bolts and set-screws, Figs. 6 to 8 , Plate 33 ; and the crossbar is again clamped to the vertical face of the rock-drill carriage, as shown in Figs. 10 and 11, Plate 34. The drills in use vary from $2 \mathrm{ft}$. 6 in. to $6 \mathrm{ft}$. $6 \mathrm{in}$. long, worked in sets, so that the right and the left-hand machine would have to a certain extent drills of equal lengths. Long and short drills work well, and in ordinary use will without sharpening drill through $10 \mathrm{ft}$. of rock each. At the end of this depth of work the arill is still sharp enough to bore $20 \mathrm{ft}$. further, but in this rock it is reduced in diameter nearly $\frac{3}{8}$ in., so that it is necessary to have the drill again jumped up, that the borehole 
may be large enough for the dynamite cartridges to pass frecly to the bottom of it. The drills used aro all of a cross section on the point, Fig. 9, Plate 33; and the cutting or abrading edge is sharpened in the forge and roughly filed up when hot, so that the leading angle is about $75^{\circ}$. Two of these drills are exhibited to the meeting; one requires jumping up and sharpening, and the other is dressed ready for boring; these clearly show the action of the rock on the tool. The whole of the castings for these machines are of phosphor bronze, the bed of wrought iron, and the remaining parts of steel.

Rocl-Drill Carriage.-The carriage for the machine is shown in Figs. 10 and 11, Plate 34, and was designed specially for this work; it has done good service and is now equal to new, the only wearing parts being the corner supporting screws $L$, the roof screw $K$, and the bearing wheels. This carriage runs on the same gauge of $21 \mathrm{in}$. as the trolleys, and when not in use is run back into the first passing place or turn-out. It is all in cast iron except the screws, nuts, and axles, and was made at Swindon from the writer's drawings. The base plate $\mathrm{M}$ of the carriage is $4 \mathrm{ft}$. $6 \mathrm{in}$. long, $2 \mathrm{ft}$. $6 \mathrm{in}$. broad, and 1 in. thick, fianged all round. The wheels are small, to keep them under the base plate and the carriage low down; and are 6 in. diam., of chilled cast iron. They rest on two heavy steel rails N, 8 ft. long, held together by three cross stud-bolts and nuts, which are advanced as the heading progresses; and matching pieces of rail are inserted behind until there is length enough to put in an ordinary rail, when the same process is again repeated. The heavy framed steel rails $N$ are always kept in front as a foundation for the carriage to rest on in working.

On the base plate is firmly bolted an A frame, with the front $\operatorname{limb}$ vertical; and through the head of it a strong screw $K$ works, $2 \frac{1}{2}$ in. diameter, so as to jack the stand firmly on its bearing screws $\mathrm{L}$, which are first run down on the rails to relieve the wheels and axles. The vertical face of the $A$ frame is planed, and has a section of 2 in. by 6 in.; and on it is a clamp $P$, which holds the crossbar or tube $J$ carrying the rock drill. This clamp clips the vertical face of the carriage and also the crossbar, and by slacking the back uuts the 
clamp and crossbar can be raised or lowered; and the front nuts similarly hold the cross tube. Only two rock-drilling machines are worked on this bar at once, as shown in Fig. 11, although four could be worked with two clamps and bars; but the writer does not think any great increase of speed would result from four being used, as. two machines now bore twenty holes in 1 hour and 6 or 7 min., and if four were used it would take nearly as long, owing to the cramped place of $6 \mathrm{ft} .6$ in. square in which the men have to work.

On the rear leg of the $A$ frame are air and water distributors, one on each side, to which are connected the air and water pipes by hose and couplings; and they are provided with outlet cocks, one for air to each machine, and one for water to each borehole. The air is brought forward by 2 in. wronght-iron pipes screwed together, and the water by $1 \frac{1}{2}$ in. and 1 in. pipes. The air pressure is $60 \mathrm{lb}$. per sq. in., and the water has a head now of $180 \mathrm{ft}$. A powerful jet of water, playing in the hole as it is bored, is found of the greatest service, especially in upward holes; the water is spurted into the boreholes through nozzles $₫$ in. diameter.

Air-Compressors or Pumps.-At first the air was pumped into the receiver by a pair of inverted single-acting cylinders, 12 in. by 15 in.; a trunk closed with a valve on the upper end worked in each cylinder, the trunks being driven by connecting rods from two opposite cranks on one shaft, on which a pulley $5 \mathrm{ft}$. diam. and a flywheel were fixed. The pulley was counterbalanced, but it was soon found that the belt, although 8 in.. broad and double, would not stand the work; consèquently a vertical engine, with $9 \frac{1}{2}$ in. by 18 in. cylinder, was coupled on at right angles to the cranks of the air pump. This worked fairly well, but the delivery and also the inlet valve gave much trouble by breaking and sticking up.

Another air pump and engine were then considered requisite to aroid any delays, keeping the old one as a stand-by; and the present air pump was designed for the purpose by the writer, as shown in Figs. 12 to 19, Plates 35 and 36. It was made intentionally larger than the present requirements, and now supplies enough air when driven at a slow speed. The air and steam cylinders are each 13 in. 
by 18 in., mounted vertical on two similar standards, and coupled to the crank-shaft at right angles to each other. The air cylinder is so made that, if anything goes wrong with the valves at either end of the cylinder, the defective cover and valves can be taken off, and the cylinder worked single-acting. There are two inlet openings for air, which is intended to be forced into the cylinder by a fan, so as always to charge it fully for each stroke; also two outlets coupled to a 4 in. pipe leading to the air receiver.

This receiver is $28 \mathrm{ft}$. long and $5 \mathrm{ft}$. diam., formerly an egg-ended boiler; it is usually kept nearly half full of water to cool the air during compression in the cylinder, as afterwards explained. The receiver is fitted with water gauge, pressure gauge, and safety valves; and a 2 in. pipe is coupled to it, leading down the shaft and to the face of the heading.

The inlet and outlet valves of the air pump are of brass, arranged four in each cover so as to give the least clearance, as shown in Figs. 14 to 16, Plate 36. They have been found to work well, not cutting or otherwise getting out of order; their weight is balanced by springs, as shown in Figs. 17 and 18.

The air cylinder is jacketed for water to keep it cool; but the jets of water that are injected keep the cylinder \&c. cool enough without the use of the jacket. At each end of the cylinder a small ball-clack is screwed into the casting; and these clacks are coupled to the lower part of the air receiver by a copper pipe, $\frac{3}{8}$ in. bore. These small clacks are so arranged that when the pressure in the air receiver is greater than that in the cylinder a jet of water is injected, and thus the air is kept sufficiently cool. The air and water are carried on together to the air receiver, where the air parts with nearly all its water. The receiver is filled half way up every week, and this quantity of water does not lower more than 6 in. during the six days' work, the water being continually circulated, heated, and cooled, through the air cylinder and receiver. The piston of the air cylinder is hollow, and kept flled with water through small holes in the top, as shown in Fig. 19, Plate 36 ; and the water has access to the circumference of the piston, to keep the rubbing surfaces lubricated in working. 
Pumping Machinery.-At first, as already stated, a Tangye "Special" pump was used; but this soon got overpowered and worn out, and the grit from the rock cut the pistons and cylinders so badly that it could not do the work required. Quick-running pumps of that or any other class are not suitable for sinking; and the writer thinks for this purpose nothing is better, when the quantity of water is not large, than a plain bucket-pump driven off a spur-wheel. The pump by which the shaft was sunk is $15 \mathrm{in}$. diam. with $\mathbf{7} \mathrm{ft}$. stroke, and is driven through a $\perp$ bob with balance boxes, off the crank-pin of a $9 \mathrm{ft}$. spur-wheel, which is geared to a pinion on the crank-shaft of a horizontal engine in the proportion of 1 to 5 . The cylinder of this engine is $18 \mathrm{in}$. by $26 \mathrm{in}$., worked with 60 to $80 \mathrm{lb}$. steam. All the parts are massive, on the locomotive type, and it is fitted with reversing gear. The ordinary speed of the pump is 10 to 12 strokes per min. The wood main-rods of the pumps are $11 \mathrm{in.} \mathrm{square,} \mathrm{and}$ as the shaft went down the bucket-lift was worked off one side of the rod, and the plunger-lift, 15 in. diameter, off the other side. After the shaft was down, this plunger was fitted to the lower end of the main rod, thus doing away with the bucket-lift and all its wear and tear, and working direct. Another similar engine and pump were then put up as a duplicate, and to bo ready to help if required. These engines were supplied with steam by two multitubular boilers, $20 \mathrm{ft}$. long and $5 \mathrm{ft}$. diam., assisted by a broad-gauge locomotive boiler.

A 40 in. Cornish beam-engine, $10 \mathrm{ft}$. stroke, was then added, with an $18 \mathrm{in}$. plunger-lift, $9 \mathrm{ft}$. stroke; this engine is very economical, and works steadily in a very satisfactory manner. As the water was still on the increase, from 80,000 to 100,000 gall. per hour, another plunger-lift, 15 in. diameter, and with the same stroke, was added to this engine. With this extra load a steam pressure of $45 \mathrm{lb}$. per sq. in. was required, cutting off at about $\frac{1}{4}$ stroke, and a vacuum of 26 to $28 \mathrm{in}$. was obtained. This engine has thrée Cornish boilers, $5 \mathrm{ft}$. 6 in. diam. and $24 \mathrm{ft}$. long, with eight Galloway cross tubes.

Near the old shaft a new one is now being sunk for permanent pumping purposes; and to do this quickly, a cross drift was driven from the present heading, and a $10 \mathrm{in}$. hole was bored down to it so as to 
unwater the ground. This new shaft is now down $150 \mathrm{ft}$. out of $200 \mathrm{ft}$. total, and will be lined with cast-iron tubbing plates; the sump for the pumps was sunk out in the dry before the $10 \mathrm{in}$. borehole was down, and the girders for carrying the pump work were built in place. The engine is a direct-acting one, with 50 in. cylinder and $10 \mathrm{ft}$. stroke, and will be fitted with a surface condenser and steam jacket; and the pump is $26 \mathrm{in.} \mathrm{diam.} \mathrm{and} 10 \mathrm{ft}$. stroke, and is worked through wrought-iron main-rods 5 in. diam. All the work in this pit is arranged for two such engines and pumps; and there will also be room for two more similar pumps, proposed to be driven by a beam engine with $72 \mathrm{in}$. cylinder and $10 \mathrm{ft}$. stroke. The valves in this and the other two pumps are Harvey's four-beat valves; they work with the least lift, and all shocks are avoided. The 50 in. engine has three boilers, $5 \mathrm{ft} .9$ in. diam. and $28 \mathrm{ft}$. long, with $3 \mathrm{ft}$. 6 in. flues, each with ten Galloway cross tubes; the working pressure will be $50 \mathrm{lb}$. per sq. in.

Mr. Geach exhibited the apparatus that had been employed in taking the soundings for determining the line of the tunnel; and also specimens of the drills used in the rock-drilling machine; showing their condition when new and after the usual amount of wear. He mentioned that in the intended visit of the members to the Severn Tunnel works after the meeting the rock-drilling machine would be shown in operation above ground, when there would be no difficulty in drilling a hole at the rate of $12 \mathrm{in}$. per min. in the same rock that was being worked in the heading, although the rate underground did not average more than 6 in. per min. Of course it was more difficult to bore the holes, as had to be done underground, at more than $\frac{3}{4}$ mile distance from the air-compressors and in a small wet heading, than it was at the surface where all was clean and dry, and the air compressors were close to, the rock-drilling machine. The tunnel when completed would he hoped be a great benefit to that neighbourhood. 
Mr. W. Froude wished to express the pleasure with which he had listened to this well-considered paper, and his appreciation of its value, showing as it did the great pains that had been taken in the investigation of the whole process which had been carried out. The machinery employed had been improved step by step, until it seemed to have arrived at a very perfect condition. He should be glad to know what was the quality of the steel used for the drills, and its hardness and temper; and under what conditions the drills were found to work most effectively.

Mr. Geach replied that the steel used for the drills was crucible cast steel, the best that could be got; and the drills were tempered as hard as possible, to a dark straw colour.

The Presinent enquired whether the machine described in the paper had been tried for boring in quartzite or in any other material harder than the Pennant rock in which the heading was being driven under the Severn.

Mr. Geach said the machine had not been at present tried in any other rock; and the particulars given in the paper were those of the work actually done in driving the heading.

Mr. T. Mongans observed that in the air compressor the steam and air cylinders were of the same diameter and stroke; and he should be glad to know what proportion the pressure of the compressed air bore to that of the steam. He also enquired whether there had been any experience with electrical blasting.

Mr. G. D. HбGHEs asked what was the number of strokes of the drill per minute that had been found to have the greatest effect.

Mr. E. A. Cowpen remarked that there were many rock-boring machines in use, some of which bored very rapidly, one he believed (Mr. Darlington's) working up to 800 strokes per min. He enquired what pressure was obtained with the air compressors described in the 
paper, and what was the number of revolutions per min. at which they worked, and the quantity of air delivered by them.

"Mr.: GEaCH replied that in the air compressors" the steam pressure omployed was from 60 to $80 \mathrm{lb}$. per sq. in., cut off at about half stroke; and the steam cylinder being coupled at right angles to the air cylinder, the air was readily compressed up to 60 or $70 \mathrm{lb}$. per sq. in.; of course the mean pressure in the air cylinder would not be equal to that in the steam eylinder, because the air was taken in only at atmospheric pressure, even supposing the air cylinder was. completely filled at the beginning of each stroke. As the stroke proceeded the pressure rose, the maximum pressure of 60 or $70 \mathrm{lb}$. being reached only in the latter part of the stroke. The speed of the air compressor to deliver the required quantity of air varied considerably with the state of repair it was in, the average speed being about. 20 rev. per min. for supplying two drills; the air cylinders and pistons were found to wear much more rapidly than the steam cylinders, owing he supposed to the water and the air combined and to the dirt that got in; on this account the quantity of air discharged could not be calculated from the speed of the compressor, and could only be ascertained correctly by actual measurement. There had not been any trouble found from the valves at all. The only feature about the air compressor which was not shown in the drawings was the arrangement for charging the inlet openings with air by means of a blowing fan driven by the engine; he did not know whether that was novel, but it was new to himself; he had not put the fan on yet, because the machine as it now was gave more air than was at present required, so there was no occasion for it.

With regard to electric firing, he had tried it, but with very poor results so far. He had succeeded in firing all the holes at once, but had never found so much rock come away with simultaneous blasting as with the ordinary system of hand-blasting with fuses. He had expected the electrical blasting would be an improvement and would do better work, but the result was the reverse, and he could not account for this; by the hand system as at present used more rock was. brought away with less dynamite than by the electric firing. 
With regard to the number of strokes per min. made by the drill, of course that varied; it was difficult to count them, but the speed was perhaps 700,800 , or even 900 strokes per min. That was simply an approximate estimate, the only means of counting the strokes being by counting the revolutions of the drill itself. In reference to the wear of the revolving parts in the drill, he thought the same principle applied as in Mr. Webb's circular slide-valve, by the rotation of which the surfaces were stated to keep in perfect condition; and so he found with the interior of the drill cylinder, and he could not see a scratch upon it even when worn out; the partial rotation of the drill at each stroke he supposed kept the surfaces true.

The Prasmenc observed that the rock-boring machine now described was rather a jumping than a drilling machine; the drill rotated between the blows, but the hole was made by jumping. In that respect it was like Captain Penrice's machine.

Mr. Geach said that was the case; and all the machines of that class were called drilling machines, but the action was jumping, although the drill did rotate between the blows; they all imitated manual action as nearly as possible. The only machine that acted as a true drill was the diamond borer of Major Beaumont, in which the hole was bored solely by the rotation of the drill under pressure, without any percussive action.

The Prestdent moved a vote of thanks to the author of the paper, and said he thought it desirable for the subject to be again brought forward for further discussion after the machine had been seen in operation. It was a very important subject, and he $\mathrm{knew}$ from his own experience that machines of this or an analogous kind were very much wanted at the present day. If it could be shown that the machine now described was superior to others, he had no doubt it would come extensively into use both in England and abroad.

The vote of thanks was passed.

The Meeting was then adjourned to the following day. 
The Adjourned Meeting was held in the Assembly Room, Grand Hotel, Bristol, on Wednesday, 25th July, 1877; Tномas Hawksletr, Esq., President, in the Chair.

The following paper was read:- 
ROCK-DRILLING MACHINE.

Plate 3i.

Sea Wall

Severn Tunnel Railway.

Fig. 1 .

General Section on line of Tunnel.

High Water

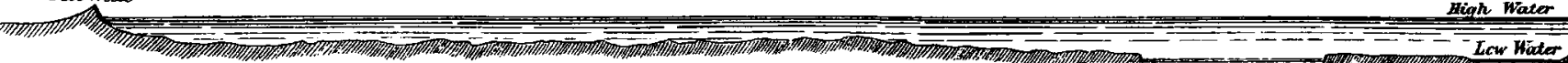

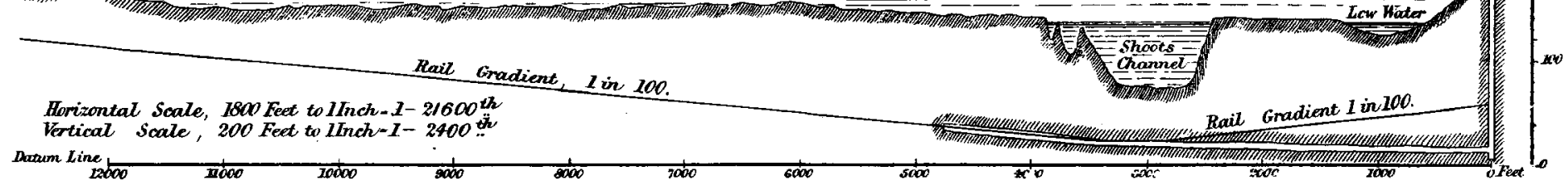

Dxam Line 12000

2000

6000

seat

ac

Fig. 2. Enlarged Section of Shaft and Heading.

High Water.

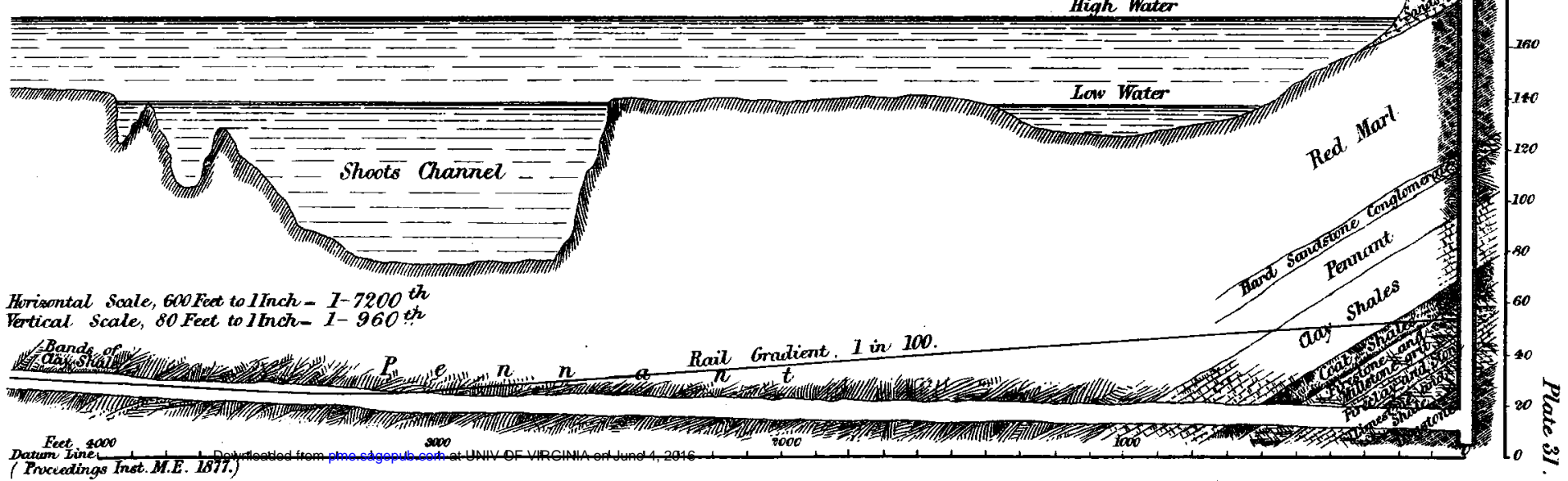


ROCK-DRILLING MACHINE.

Rock-Drilling Machine at Severn Tunnel Works.
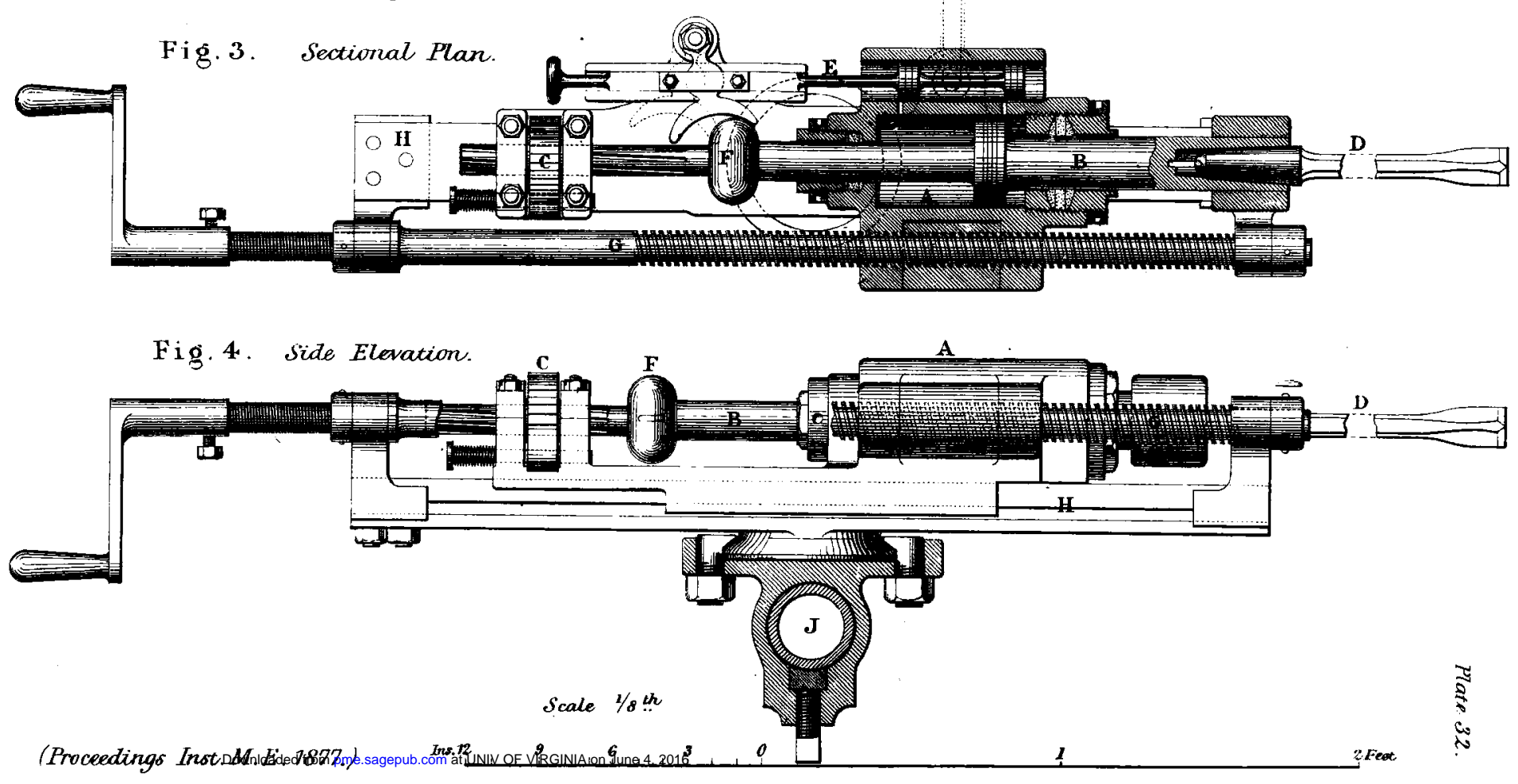


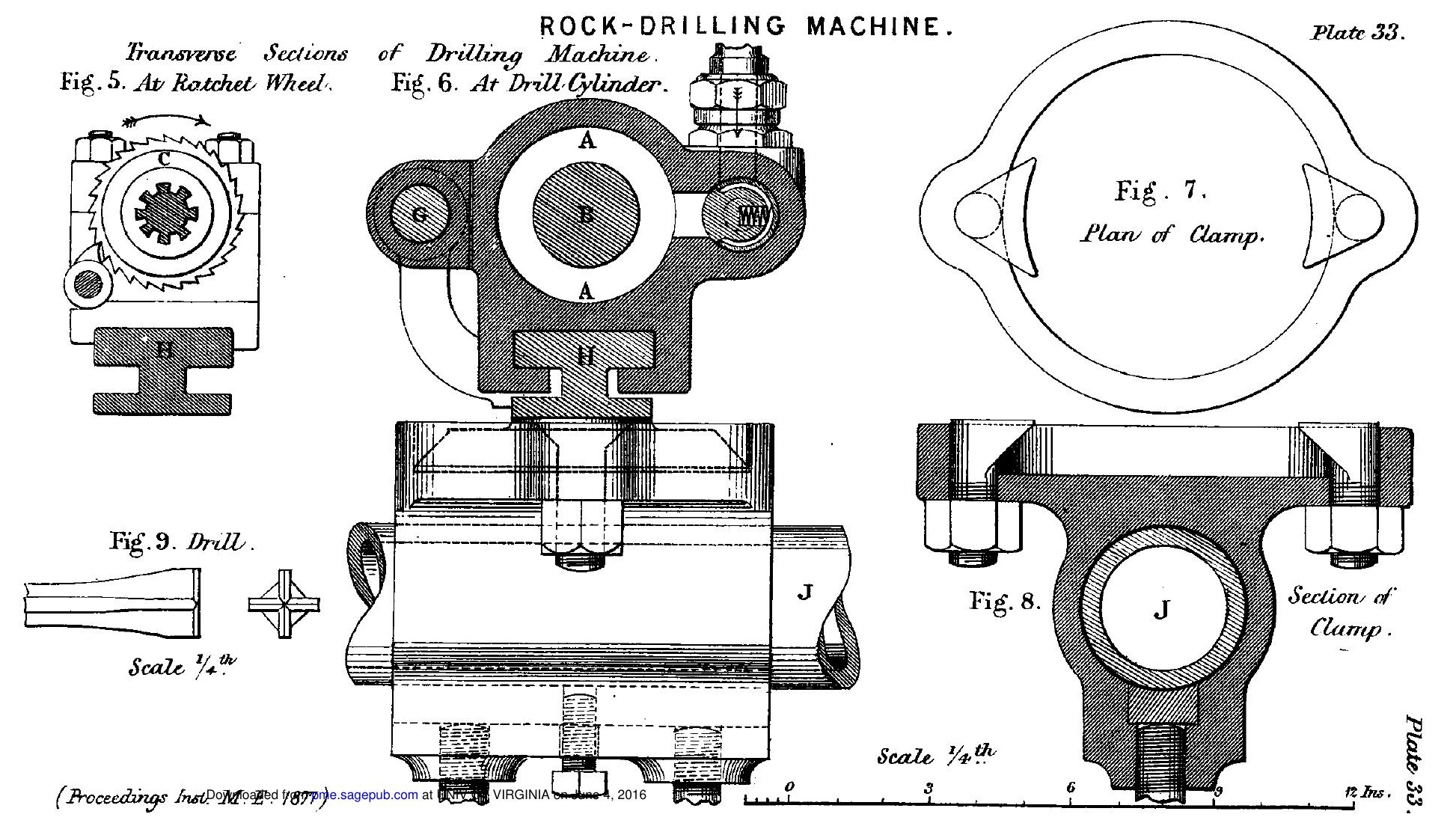


Fig. 10. Side Elevation
Drill Carriage
Hig.11. Lind Alevation.
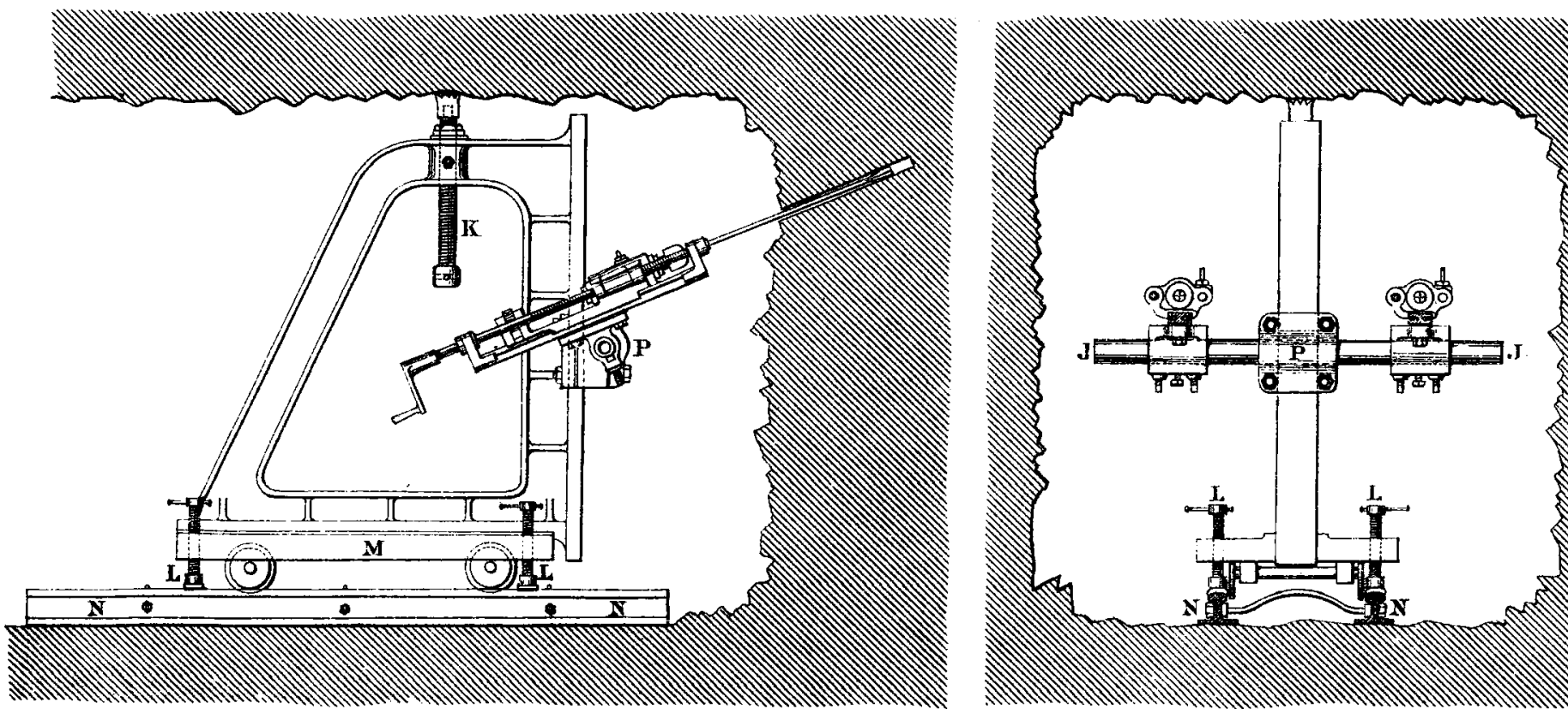

Scale sot

Ins. 12

0

(Proceedengs Ihst. M.E. 1877)

Downloaded from pme.sagepub.com at UNIV OF VIRGINIA on June 4, 2016 


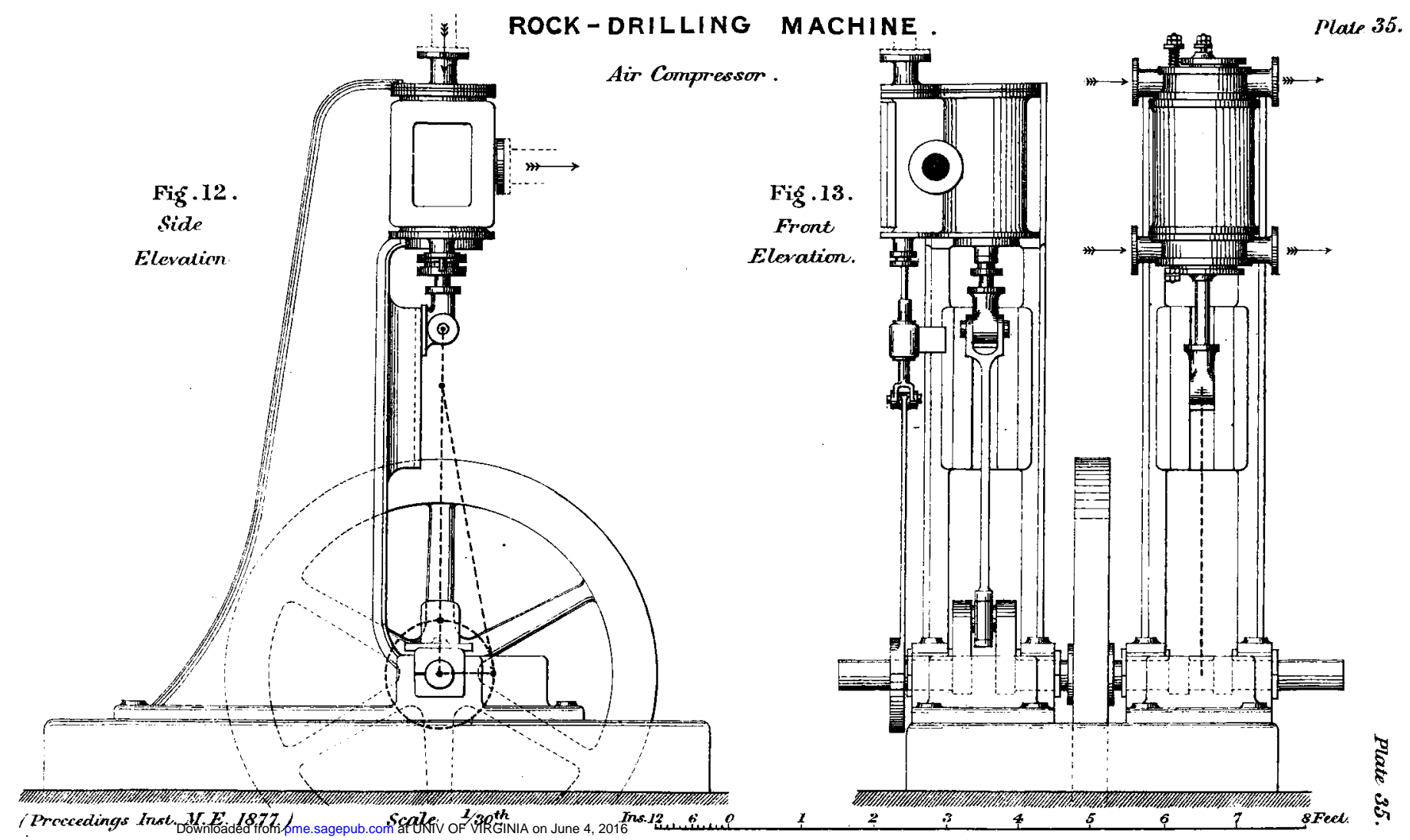


Fig. 14.

Vertical Section of Air Gylinder.

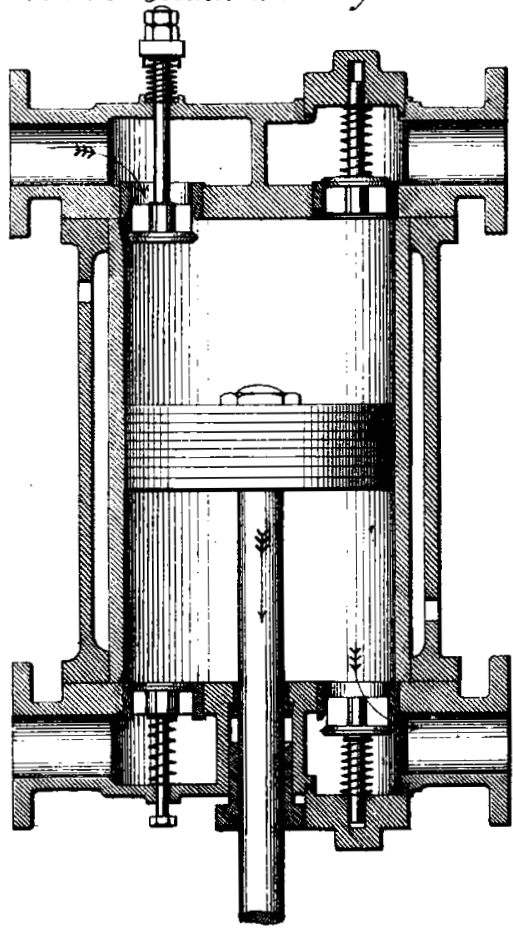

Scale $1 / 12$ th
ROCK-DRILLING MACHINE.

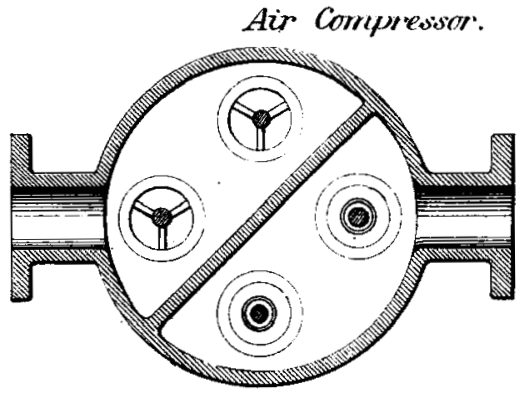

Fig.15. Top Valve-Chest.

Sectional Plans.

Fig. 16. Bottorn Vature-Chest.

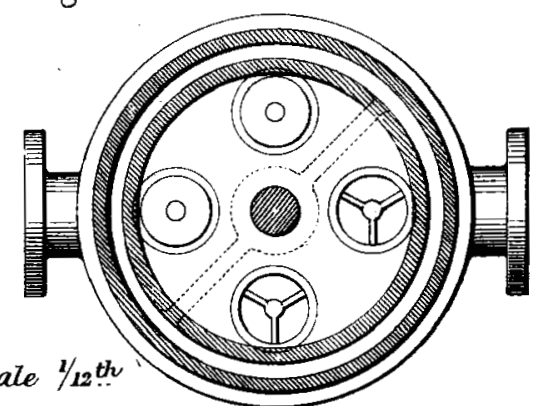

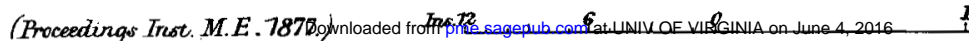

i.

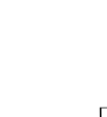

10

Plate 36 .

Air Valwes.

Fig.17. Fig. 18 .

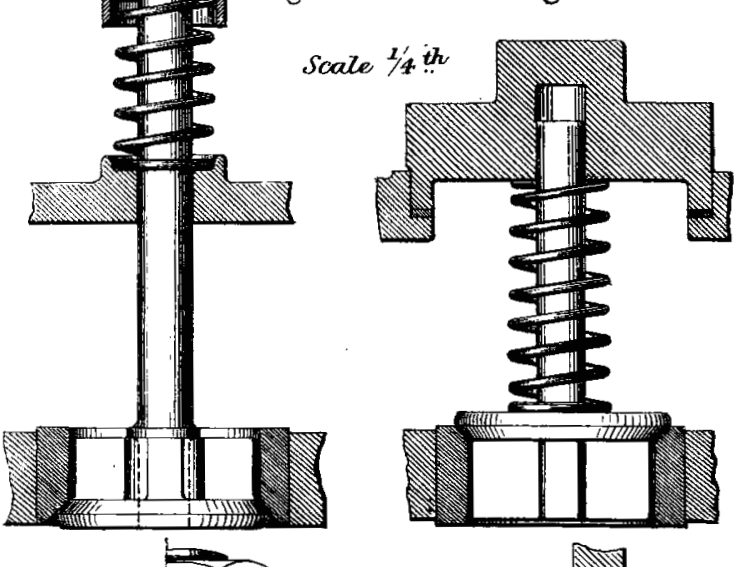

Fig. 19. Section of : Piston. Scale $1 / s^{\text {th }}$ 3Feat 